\section{Nauplius}

The Journal OF The Brazilian Crustacean Society

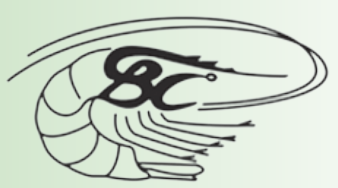

e-ISSN 2358-2936

www.scielo.br/nau www.crustacea.org.br
This article is part of the tribute offered by the Brazilian Crustacean Society in memoriam of Michael Türkay for his outstanding contribution to Carcinology

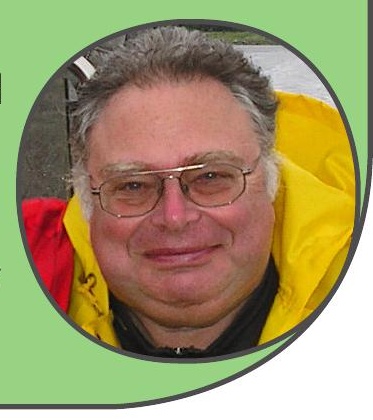

Original Article

\title{
Enosteoides Johnson, 1970 (Crustacea: Decapoda: Anomura: Porcellanidae) from the Central Philippines, with description of a new species of the genus
}

Masayuki Osawa

Research Center for Coastal Lagoon Environments, Shimane University, 1060 Nishikawatsu-cho, Matsue, Shimane 690-8504, Japan.

ZOOBANK http://zoobank.org/urn:lsid:zoobank.org:pub:D612F858-D9C1-43EC850E -57E29B2411B1

\section{Abstract}

Three species of the porcellanid genus Enosteoides Johnson, 1970, including a new species, are reported from the Central Philippines on the basis of material mainly collected by the PANGLAO Marine Biodiversity Project 2004. Enosteoides lobatus Osawa, 2009 and E. palauensis (Nakasone and Miyake, 1968) are new to the Philippine crustacean fauna. Enosteoides turkayi n. sp. is most closely allied to E. melissa (Miyake, 1942) and E. philippinensis Dolorosa and Werding, 2014 in the shape and structure of the rostrum and chelipeds and the comparatively slender second to fourth pereopods. However, the new species is distinguished from E. melissa and E. philippinensis by the third thoracic sternite without an anteriorly produced median lobe and the carpi and propodi of the second to fourth pereopods being bright red for the most part.

\section{KEY WORDS}

New porcelain crab, new record, PANGLAO 2004, Southeast Asia, taxonomy.

Masayuki Osawa

osawam@soc.shimane-u.ac.jp

SUBMITTED 27 May 2016

ACCEPTED 15 July 2016

PUBLISHED 22 September 2016

Guest Editor

Célio Magalhães

DOI 10.1590/2358-2936e2016013

\section{INTRODUCTION}

Enosteoides Johnson, 1970 is a small porcellanid genus that includes five species known from the Indo-West Pacific (Osawa and McLaughlin, 2010; Dolorosa and Werding, 2014): E. lobatus Osawa, 2009, E. melissa (Miyake, 1942), E. ornatus (Stimpson, 1858) [= Porcellana corallicola Haswell, 1882; 
type species of the genus], E. palauensis (Nakasone and Miyake, 1968), and E. philippinensis Dolorosa and Werding, 2014. The genus is characterized by the carapace having well-defined dorsal regions and some spines on each lateral margin, the rostrum with a median concavity or notch on the anterior margin in dorsal view, the second to fourth articles of the antennal peduncle excluded from the orbit by the projection of the first article adpressed to the anterior margin of the carapace, and the chelae flattened (Haig, 1978; Osawa, 2009; Osawa and Chan, 2010).

The PANGLAO 2004 Marine Biodiversity Project was an international survey of marine fauna, with emphasis on crustaceans and mollusks, conducted in May-July 2004 around the island of Panglao located southwest offBohol in the Central Philippines (Bouchet et al., 2009). Based on the material mainly collected by the PANGLAO Marine Biodiversity Project 2004, the present paper reports three species of the genus Enosteoides including a new species and two known species that are new to the Philippine crustacean fauna.

\section{Materials and Methods}

The holotype of the new species is deposited in the crustacean collection of the National Museum of the Philippines, Manila (NMCR), and paratypes and other specimens are located in the Zoological Reference Collection of the Lee Kong Chian Natural History Museum, National University of Singapore, Singapore (formerly known as the Raffles Museum of Biodiversity Research, ZRC).

Carapace length $(\mathrm{cl})$ was measured from the anterior median tip of the rostrum to the posteromedian margin of the carapace. Measurements of the chelipeds were made as: carpus length along the posterior margin (excluding the distal projection) and breadth on the dorsal transverse midline (excluding the anterior teeth), chela length along the anterior margin and breadth along the dorsodistal transverse line of the palm, and dactylus length along the posterior margin. Measurements of the ambulatory legs were made as: merus length along the dorsal margin, propodus length along the dorsal margin and height on the lateral transverse line at the base of the distal round projection, and dactylus length along the dorsal margin. Terminology mainly follows that of Osawa and Chan (2010), except for the uses of "dorsal" and "ventral" for "extensor" and "flexor" margins in the third maxilliped and ambulatory legs and "anterior" and "posterior" for "flexor" and "extensor" margins or surfaces in the chelipeds. For comparison, specimens of Enosteoides melissa were also examined. They are deposited in the collections of the Kitakyushu Museum of Natural History and Human History (previously Zoological Laboratory, Faculty of Agriculture, the Kyushu University; ZLKU); Natural History Museum and Institute, Chiba (CBM); and the University Museum Fujukan, University of the Ryukyus (RUMF).

Palau: Off Ngatmél, Babldáob Island, 14 March 1938, coll. S. Murakami, holotype, female (cl $8.5 \mathrm{~mm}$ ), ZLKU 4265. Japan, Ryukyu Islands: Hoshizunanohama, Sumiyoshi, Iriomote Island, intertidal, under rock on sea grass area, 14 July 2000, coll. T. Komai, 1 ovigerous female (cl $8.7 \mathrm{~mm})$, CBMZC 9470. - Misaki, Kitanakagusuku, Okinawa Island, intertidal, sea grass bed on sand, burrows, occurred together with Alpheus rapax Fabricius, 1798 and Eurythoe complanata (Pallas, 1766), suction pump, 15 April 2010, coll. M. Osawa, 2 males (cl 10.7, 12.6 $\mathrm{mm}), 1$ female parasitized by bopyrid (cl $11.9 \mathrm{~mm}$, Fig. 1A), RUMF-ZC 4310.

\section{SYSTEMATICS}

\section{Family Porcellanidae Haworth, 1825}

\section{Genus Enosteoides Johnson, 1970}

\section{Enosteoides lobatus Osawa, 2009}

Enosteoides lobatus Osawa, 2009: 158, figs. 1-3, 4A, B (type locality: Okinawa Island, Ryukyu Islands; low intertidal). - Osawa and McLaughlin, 2010: 110 (list), 126, fig. 1B.

Material examined. Philippines, PANGLAO 2004: Looc, Panglao Island, stn S18, 9³5.7'N 12344.4'E, 0-2 m, subtidal platform, mixed bottoms, 18 June 2004, 1 ovigerous female (cl $2.5 \mathrm{~mm})$, ZRC 2016.0057.

Coloration. Unknown in the present specimen. In the fresh specimens collected from the Ryukyu Islands, the carapace is cream or reddish brown, and the chelipeds and second to fourth pereopods (ambulatory 
legs) are reddish brown (Osawa, 2009; Osawa and McLaughlin, 2010).

Distribution. Previously only known from the Ryukyu Islands in south Japan, intertidal to subtidal depths of 3-5 m, under rock or within narrow space underneath dead coral block (Osawa, 2009). Now also from the Philippines.

Werding et al. (2016) found material of E. lobatus from Papua New Guinea in the collection of the Muséum National d'Histoire Naturelle (MNHN), Paris, and also recorded the species based on direct field observations in the Lembeh Strait, Indonesia. However, the specimens that they observed in the Lembeh Strait are probably referred to E. turkayi n. sp. described below, not E. lobatus (see the Remarks for the new species).

Remarks. The present specimen agrees well with the original description of E. lobatus by Osawa (2009). It is the smallest $(\mathrm{cl} 2.5 \mathrm{~mm})$ among the reported specimens and is ovigerous. This is the second occurrence record of this rare species.

\section{Enosteoides palauensis \\ (Nakasone and Miyake, 1968)}

(Fig. 1B)

Porcellana melissa Miyake, 1942: 367 (part), text-fig. 27 (not P. melissa Miyake, 1942).

Porcellana palauensis Nakasone and Miyake, 1968: 165, fig. 1, pl. 7-fig. A (type locality: Ngadarák Reef, Palau Islands; low intertidal).

Enosteoides palauensis. - Haig, 1978: 709. Osawa, 2007: 11; 2009: 165, fig. 4D. - Osawa and McLaughlin, 2010: 110 (list).

Enosteoides hainanensis Yang and Sun, 2005: 19, figs. 15, 16 (type locality: Hainan Island, South China Sea).

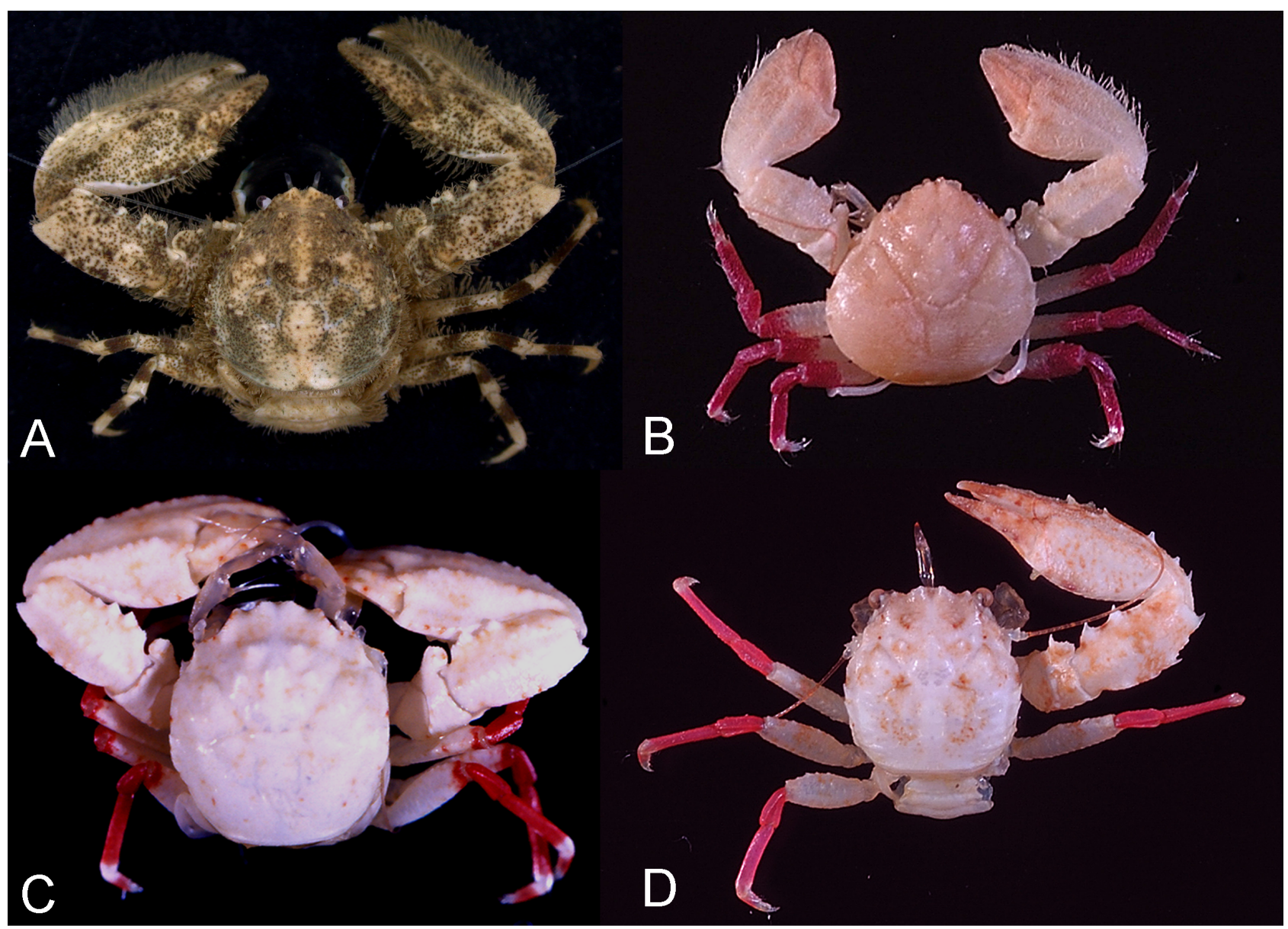

Figure 1. Entire animal, dorsal view. A, Enosteoides melissa (Miyake, 1942), male (cl 12.6 mm), RUMF-ZC 4310, Okinawa Island; B, Enosteoides palauensis (Nakasone and Miyake, 1968), female parasitized by rhizocephalan (cl 2.6 mm), ZRC 2016.0058, Panglao Island, stn S7; C, Enosteoides turkayi n. sp., holotype, female (cl 4.5 mm), NMCR, Balicasag Island; D, Enosteoides turkayi n. sp., missing specimen, Panglao Island, stn T4. 
Material examined. Philippines, PANGLAO 2004: Sungcolan Bay, Panglao Island, stn S7, 9³8.5’ N $123^{\circ} 49.2^{\prime} \mathrm{E}, 1-4 \mathrm{~m}$, sand with seagrass, 9 June 2004, 1 female parasitized by rhizocephalan ( $\mathrm{cl} 2.6 \mathrm{~mm})$, ZRC 2016.0058.

Coloration (Fig. 1B). Carapace and chelipeds generally white with pale brown tint. Second to fourth pereopods with meri white on proximal 0.7 and remaining part dark red; carpi and propodi entirely dark red; dactyli also dark red proximally and whitish distally.

Distribution. Ryukyu Islands in south Japan, Hainan Island in south China, Palau, and New Caledonia; low intertidal to subtidal depths of 7-31 m; interspace of dead coral block (Osawa, 2007; 2009). Now also from the Philippine waters.

Remarks. The present specimen agrees well with the original description by Nakasone and Miyake (1968, as Porcellana) and a short description by Osawa (2009) of E. palauensis. Osawa (2007) considered that E. hainanensis Yang and Sun, 2005 is synonymous with E. palauensis because the distinctions discussed by Yang and Sun (2005) were insufficient to distinguish the two species based on the re-examination of the type material of E. palauensis.

The sole specimen examined is parasitized by a rhizocephalan of the family Lernaeodiscidae.

\section{Enosteoides turkayi n. sp.}

$$
\text { (Figs. 1C, D, 2-4) }
$$

Type material. Holotype. Balicasag Island, Philippines, 80-150 m, 6-10 March 1999, tangle net, coll. T. Kase, female (cl $4.5 \mathrm{~mm}$ ), NMCR. Paratypes. Philippines, PANGLAO 2004: Catarman, Panglao Island, stn B7, 9³5.9’ $\mathrm{N} 123^{\circ} 51.8^{\prime} \mathrm{E}, 4-30 \mathrm{~m}$, reef slope with caves, 5 June 2004, 1 ovigerous female (cl $2.3 \mathrm{~mm}$ ), ZRC 2016.0059. - Baclayon Takot, Bohol Island, stn B13, 9'37.1'N 12352.6'E, 3-5 m, coral rubble, 15 June 2004, 1 ovigerous female (cl $2.5 \mathrm{~mm}$ ), ZRC 2016.0060. — Black Forest, Balicasag Island, stn B23, $9^{\circ} 31.1^{\prime} \mathrm{N} 123^{\circ} 41.3^{\prime} \mathrm{E}, 20-25 \mathrm{~m}$, rubble on sand, 25 June 2004, 1 male (cl 4.5 mm), ZRC 2016.0061. — Bolod,
Panglao Island, stn T4, 9 $33.0^{\prime} \mathrm{N} 123^{\circ} 48.5^{\prime} \mathrm{E}, 82 \mathrm{~m}$, many large sponges, 1 June 2004, 1 ovigerous female (cl $3.9 \mathrm{~mm}$ ), ZRC 2016.0062. - Biking, Panglao Island, stn $\mathrm{T} 29,9^{\circ} 34.5^{\prime} \mathrm{N} 123^{\circ} 50.6^{\prime} \mathrm{E}, 77-84 \mathrm{~m}$, mud, 1 July 2004, 1 male (cl $2.8 \mathrm{~mm}), 2$ females (cl 2.9, $3.6 \mathrm{~mm}$ ), ZRC 2016.0063.

Description. Carapace (Fig. 2A, B) 1.0-1.1 times longer than broad; dorsal surface somewhat convex from side to side, strongly uneven, with some short plumose setae on each ridges (more numerous along lateral margins); regions well demarcated; pair of protogastric crests well marked, blunt; weak or moderately strong swelling present lateral to each protogastric crest; gastric and anterior branchial regions strongly elevated, with some short, minutely tuberculate or granular ridges; each anterior branchial region sectioned 2 parts by shallow obliquely longitudinal groove; cervical grooves relatively deep; median branchial regions each with low swelling; lateral brachial and cardiac regions covered with short granular ridges. Rostrum (Fig. 2C) broad, 0.5 carapace width (measured at posterior ends of ocular peduncle in dorsal view), trilobate, slightly directed downward; median lobe exceeding and approximately twice as broad as lateral lobe, with distinct groove on dorsal midline; anterior margin concave or slightly convex in dorsal view; anterior median apex strongly bent ventrally, terminating subacutely; lateral lobes low, subtriangular, terminating bluntly or with small distal blunt or acute spine. Orbits shallow, supraorbital margins weakly concave, outer orbital angles each terminating in small blunt projection. Hepatic margins weakly convex, each with row of granules. Branchial margins moderately convex, constricted on posterior 0.3, each elevated to form thin, granular or minutely denticulate crest and with 1 or 2 small median spines followed by 1 or 2 low protuberances; posterior margins with long, oblique, blunt ridges.

Pterygostomial flap (Fig. 2B, D) with longitudinal, minutely tuberculate ridges, anteriorly terminating in acute projection, slightly concave on anterodorsal surface; dorsal margin with strong spine on anterior 0.2 .

Third thoracic sternite (Fig. 2E) with ventral surface slightly convex medially; anterior median margin concave; lateral lobes narrow, each with rounded apex. Fourth thoracic sternite incompletely separated from third sternite, slightly convex medially on ventral 

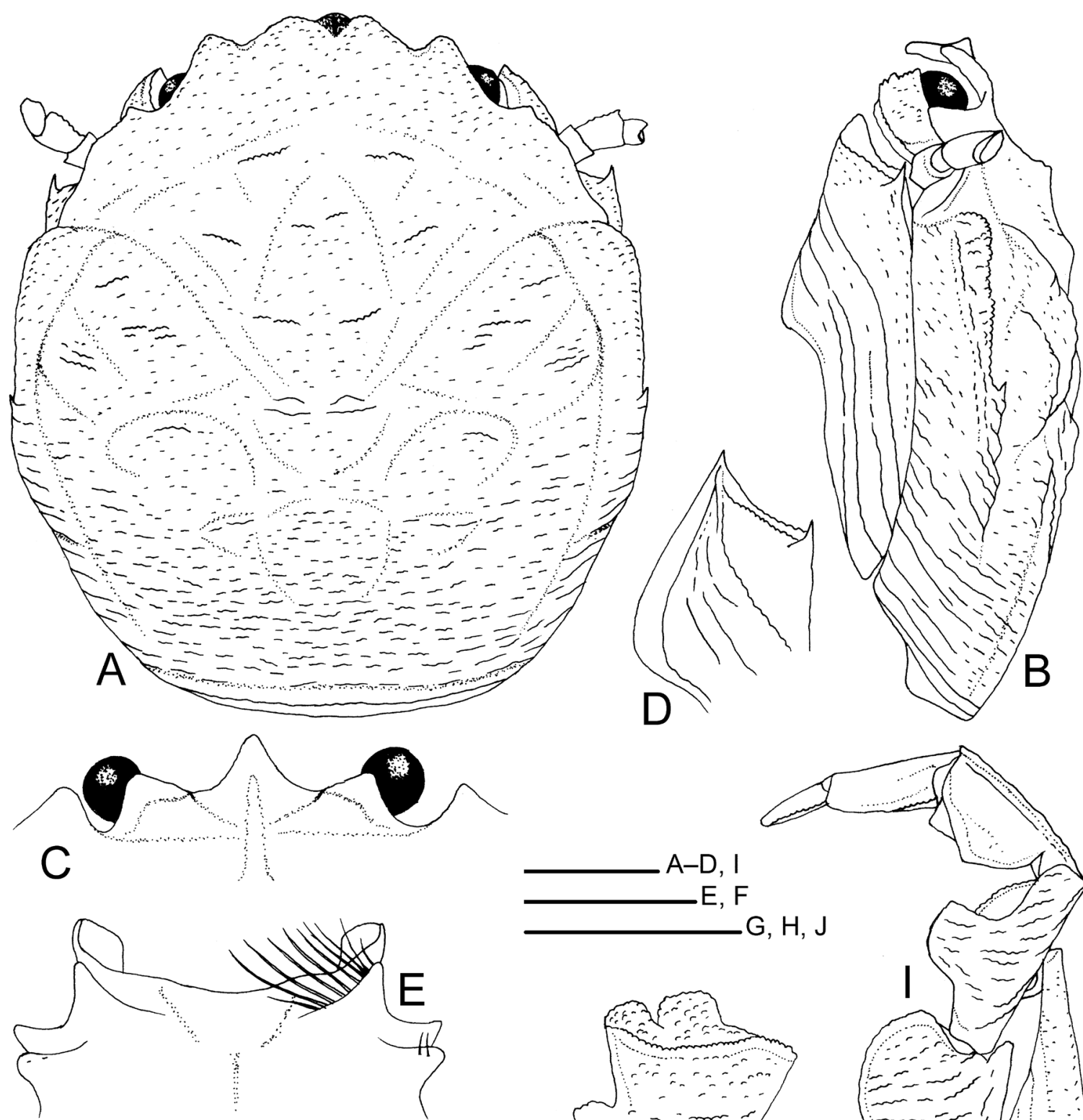

$\mathrm{G}, \mathrm{H}, \mathrm{J}$
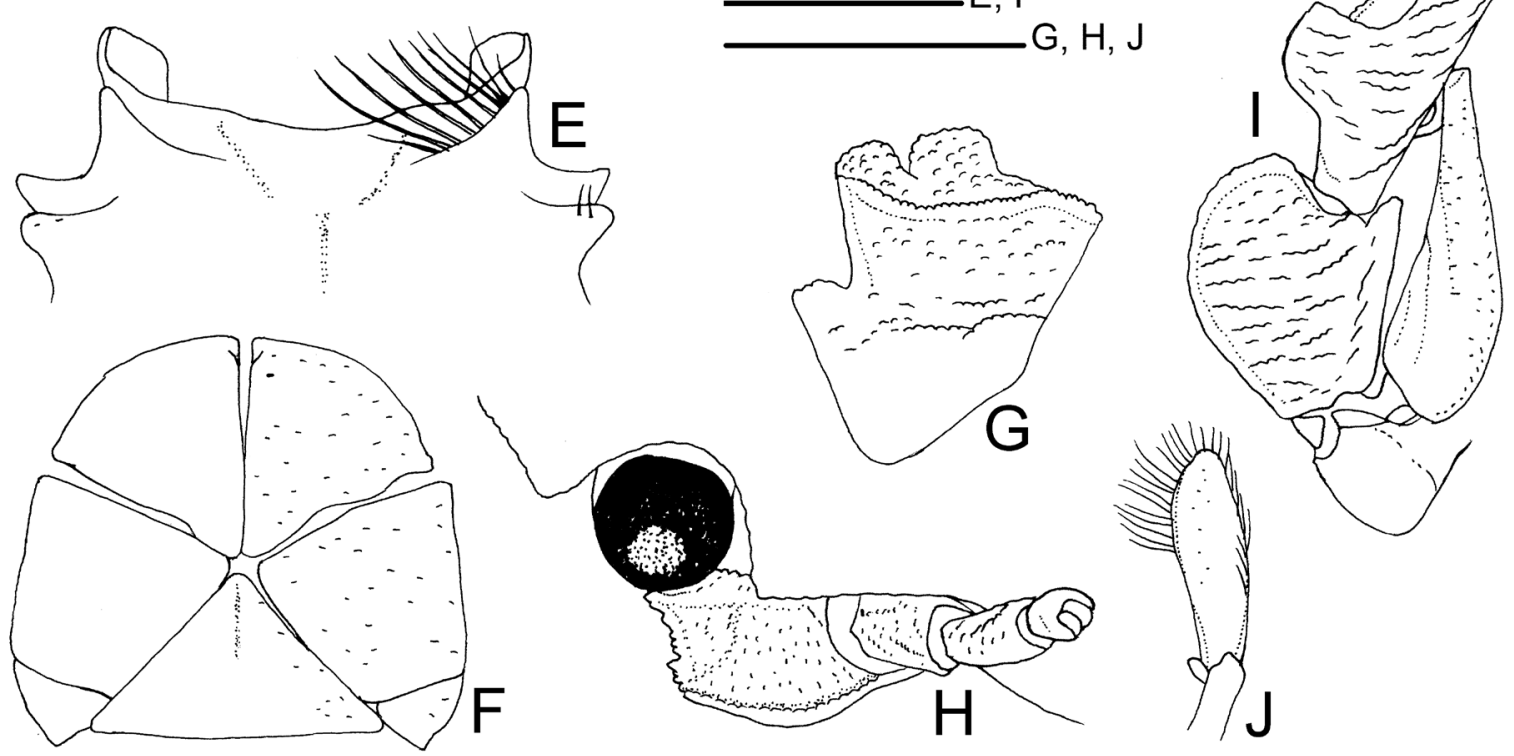

Figure 2. Enosteoides turkayi n. sp. Holotype, female ( $\mathrm{cl} 4.5 \mathrm{~mm}$ ), NMCR, Balicasag Island (A-I); paratype, male (cl $4.5 \mathrm{~mm}$ ), ZRC 2016.0061, Balicasag Island, stn B23 (J). A, carapace, pterygostomial flap, and ocular and antennal peduncles, dorsal view; B, same, left side, lateral view; C, rostrum, and ocular peduncles, frontal view; D, anterior part of left pterygostomial flap, ventrolateral view; E, third and fourth thoracic sternites, ventral view (setae omitted from right side); F, telson, external view (surface structure omitted from right side); G, basal article of left antennular peduncle, ventral view; $\mathrm{H}$, left anterior part of carapace and ocular and antennal peduncles, anterolateral view; I, left third maxilliped, lateral view (long setae on ventral margin omitted); J, right second pleopod (gonopod), ventral (posterior) view. Scale bars $=1.0 \mathrm{~mm}$. 
surface; anterolateral margins each with row of setae. Subsequent sternites convex on ventral surface, with longitudinal groove on midline.

Ocular peduncles (Fig. 2A-C, H) relatively small; dorsal extension onto cornea low, rounded.

Basal article of antennular peduncles (Fig. 2G) slightly longer than broad; anterior surface separated from ventral surface by transverse ridge of minute tubercles, bearing scattered granules; anterior margin with 2 bluntly truncate lobes mesially; ventral surface with transverse ridges on median lateral part.

Antennal peduncles (Fig. 2A, B, H) generally short, slender. First article largest, strongly produced forward in lateral view, broadly in contact with lower orbital margin, with longitudinal, minutely tuberculate ridge along ventral margin; lateral surface slightly concave; anterior margin terminating subacutely. Second article slightly granular. Third article subrectangular, somewhat broadened distally; anterior surface with granules. Fourth article short, rounded.

Third maxilliped (Fig. 2I) with coxa bearing small, distal subtriangular projection on ventral margin; distomedian projection with proximal suture. Basis small, not fused with ischium, roundly triangular. Ischium broad, ventral surface with transverse granular ridges and row of oblique ridges along extensor margin, disto-extensor projection rounded. Merus with laminate, broad, roundly subrectangular lobe on ventral margin; lateral surface with transverse ridges. Carpus with subtriangular projection on median part of ventral margin, lateral surface with longitudinal ridge along dorsal margin. Propodus slender, nearly smooth. Dactylus elongate ovate. Merus to dactylus with long plumose setae on ventral margin. Exopod with proximal article small, rounded; distal article laminated, reaching midlength of merus; proximal part of distal article inflated; flagellum well developed.

Chelipeds (first pereopods) (Figs. 3A-G, 4A, $B$ ) nearly equal or slightly unequal in size, generally identical to each other, flattened; dorsal surface of each article with numerous granules; ventral surface of each article covered with short or very short, granular ridges; margins of ischium to carpus with sparse plumose setae. Merus with transverse series of short granular ridges and blunt transverse crest submedially on dorsal surface; dorsoanterior margin with rounded lobe, margin of lobe crenulated, with or without small spine anterodistally; dorsodistal margin with small tubercle or acute spine at lateral angle; ventrodistal margin with strong spine at anterior angle. Carpus 1.6-1.7 times as long as broad; dorso-anterior margin minutely tuberculate or dentate, with 2 or 3 blunt or acute teeth on proximal half; dorsal surface with longitudinal elevated crest of short row of beaded granules on midline; posterior margin with weakly crenulated crest bearing 2 or 3 small spines proximally followed by blunt or subacute protuberances; ventroanterior margin with row of small, blunt or subacute denticles. Chela moderately broad, $2.1-2.3$ times as long as carpus, 2.0-2.2 times as long as broad; anterior margin slightly convex, thin, with row of small, blunt or subacute denticles and sparse or numerous plumose setae on entire length and with some small but distinct spines on proximal half. Palm weakly convex on dorsal surface; longitudinal, elevated crest of short rows of beaded granules present on dorsomidline; posterior margin slightly elevated dorsally to form blunt, weakly crenulated crest; ventral surface convex on midline, sometimes with sparse, short plumose setae, anterior half somewhat concave. Fixed finger terminating in short blunt claw; dorsal surface with longitudinal, blunt crest along midline; cutting edge nearly straight, with no distinct teeth. Dactylus 0.4-0.5 length of chela, opening at slight oblique angle, terminating in curved, blunt claw; dorsal surface bluntly elevated on midline; posterior margin slightly elevated to form blunt crest; cutting edge nearly straight, with row of small blunt teeth; ventral surface flattish. Ventrodistal posterior part of palm and cutting regions of fixed finger and dactylus with dense plumose setae.

Ambulatory legs (second to fourth pereopods) (Fig. 3C-G) relatively slender, decreasing in size posteriorly; dorsal and ventral margins with sparse, plumose and simple setae on meri and with only simple setae on carpi to dactyli; lateral surface of merus of fourth pereopod with some, moderately long simple setae. Meri somewhat compressed laterally, elongate subrectangular, decreasing in length posteriorly, 2.1 (fourth pereopod, 2.5 in holotype)-3.5 (second pereopod, holotype) times as long as maximum high; dorsal margin slightly convex, weakly crenulate; lateral surface with series of short transverse ridges; mesial surface with short, granular, transverse ridges; ventrodistal margins of lateral and mesial surfaces 


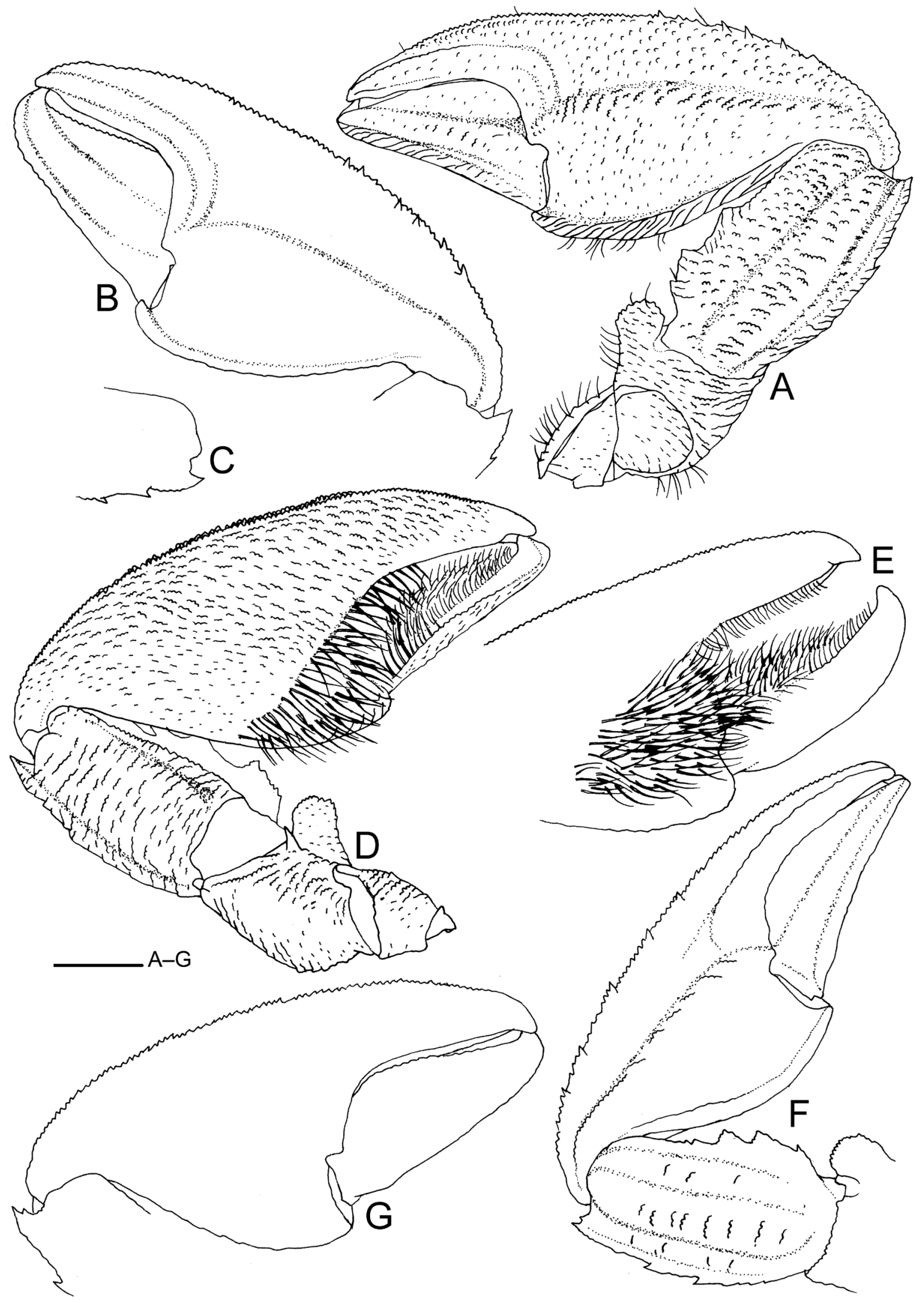

Figure 3. Enosteoides turkayi n. sp., holotype, female (cl $4.5 \mathrm{~mm}$ ), NMCR, Balicasag Island. A, right cheliped, dorsal view; B, same, distal part of carpus, dorso-anterior view; C, same, chela, dorso-anterior view; D, same, ventral view; E, same, distal part of chela, ventroposterior view; F, left cheliped, dorsal view; G, same, chela, dorso-anterior view. Scale bar $=1.0 \mathrm{~mm}$. 


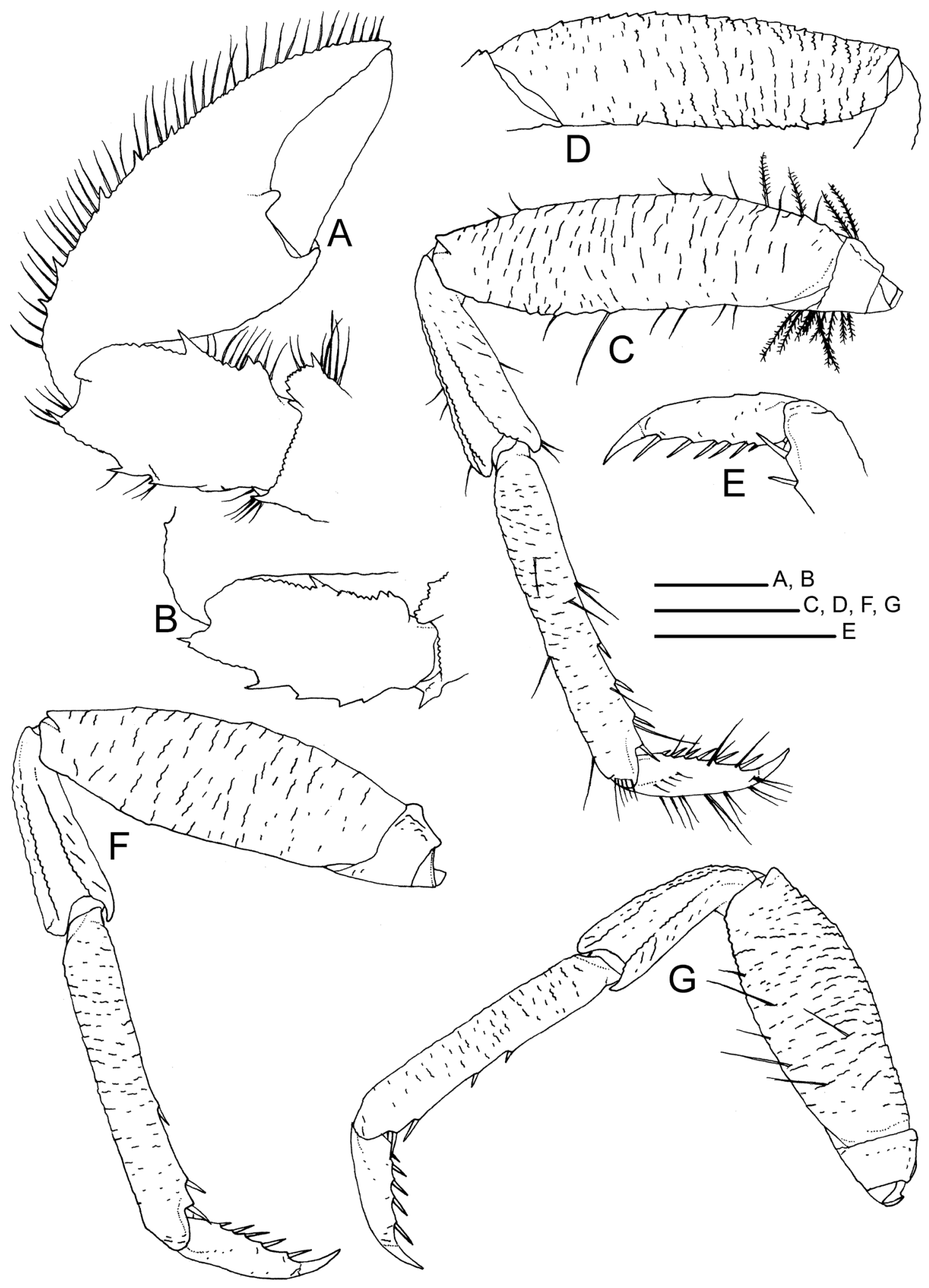

Figure 4. Enosteoides turkayi n. sp. Paratype, female (cl3.6 mm), ZRC 2016.0063, Balicasag Island, stn T29 (A, B); holotype, female (cl $4.5 \mathrm{~mm}$ ), NMCR, Balicasag Island (C-G). A, left cheliped, dorsal view (plumose setae simplified); B, same, carpus and distal part of merus, dorso-anterior view; C, left second pereopod, lateral view; $\mathrm{D}$, same, merus, mesial view; E, same, dactylus and distal part of propodus, lateral view; F, left third pereopod, lateral view (setae on margins omitted); G, left fourth pereopod, lateral view (setae on margins omitted). Scale bars $=1.0 \mathrm{~mm}$. 
rounded, unarmed. Carpi elongate; lateral surface with 2 granular crests each along dorsal margin and midline; dorsal surface minutely tuberculate or dentate; dorsodistal and ventrodistal margins rounded; mesial surface with short, transverse ridges of granules. Propodi 2.8 (third pereopod, 3.1 in holotype) -3.4 (second pereopod, holotype) times as long as dactyli, 4.6 (fourth pereopod, 6.1 in holotype)-6.9 (second pereopod, holotype) times as long as high; lateral surface with scattered, short ridges; dorsal margin weakly crenulated; ventral margin with 2-4 (usually 2 or 3 ) corneous spines; distoventral margin with paired spines subequal in size; mesial surface with short, transverse ridges of granules on proximal 0.7. Dactyli nearly smooth, each terminating in weakly curved, slender claw; ventral margin with 4-6 (usually 4 or 5 ) corneous spines.

Fifth pereopod short, slender, chelate; propodus with tuft of short simple setae on distoflexor margin; fixed finger and distal part of palm with short simple setae and about 30 scythe-like setae on flexor surface; dactylus and distal part of palm with simple setae of irregular sizes on extensor surface.

Telson (Fig. 2F) composed of 7 plates, broader than long, generally similar between male and female; posterior plates slightly longer than broad.

Male with pair of pleopods modified as gonopods on second abdominal segment (Fig. 2J); endopod elongate ovate, not distinctly twisted, with marginal setae; exopod small. Female with pairs of developed pleopods on third to fifth abdominal segments, third pair slightly smaller than fourth and fifth pairs.

Variation. Two large specimens (cl $4.5 \mathrm{~mm}$ : female holotype, NMCR, and male paratype, ZRC 2016.0061) differ from other smaller specimens (cl2.3-3.9 mm) in some characters. The short plumose setae on the ridges of the dorsal carapace surface are reduced in size and number in the two large specimens than in the others. The sharply pointed spines on the posterior margin of the carpus and anterior margin of the palm of the cheliped in the small specimens greatly weaken in the two large specimens. The anterior margin of the chela also has a distinct row of plumose setae in the small specimens, but it bears only a few very short setae in the two large specimens.
Coloration (Fig. 1C, D). Carapace and chelipeds generally white, with reddish and dark brown blotches. Second to fourth pereopods with meri white on entire part or proximal 0.9 with remaining part bright red; entire parts of carpi and proximal 0.9 of propodi bright red, distal 0.1 of propodi white; dactyli whitish, each with pale or bright red band medially.

Distribution. Central Philippines around Bohol, Panglao, and Balicasag Islands; depths ranging from 3-5 to 80-150 m; coral rubble, sand, and mud.

Etymology. The present new species is named in honor of the late Dr. Michael Türkay, for his great contribution to the systematics of various groups of decapod crustaceans.

Remarks. The new species resembles E. melissa and E. philippinensis in that the rostrum is at most slightly tuberculate on the anterior margin and has lateral lobes usually bluntly produced, the palm of the cheliped is moderately broad and not distinctly tuberculate on the dorsal surface, and the meri and propodi of the second to fourth pereopods are relatively slender. However, E. turkayi n. sp. is immediately distinguished from $E$. melissa and E. philippinensis by having the third thoracic sternite without an anteriorly produced median lobe, unlike the distinct and broadly rounded median lobe in the latter two species. Additionally, E. turkayi n. sp. lacks some, distinct rounded tubercles on the gastric region and anterior branchial regions of the carapace as possessed by E. melissa and E. philippinensis, and has much less setose pereopods than in the latter two species. The shape of the third thoracic sternite links $E$. turkayi n. sp. to E. lobatus, but the latter species clearly differs from the new species in having the lateral lobes of the rostrum that are narrow and subtriangular, instead of broader and usually bluntly produced and in the absence of dense plumose setae on the ventroposterior distal surface of the chela and cutting regions of the fingers.

The fresh coloration also distinguishes E. turkayi $\mathrm{n}$. sp. from E. melissa and E. philippinensis. The carapace and chelipeds are generally white with brown blotches in the new species, instead of being pale pink to brown or mottled dark brown in E. melissa and E. philippinensis. The carpi and propodi of the second to 
fourth pereopods are bright red for most part in the new species, whereas such color pattern is not seen in E. melissa and E. philippinensis (Osawa, 2009; 2013; Dolorosa and Werding, 2014; Fig. 1A). The red-colored carpi and propodi of the ambulatory legs are shared by E. palauensis and E. turkayi n. sp. However, E. palauensis is different from E. turkayin. sp. by having the narrower rostrum with indistinct lateral lobes, the broader chelae, and the comparatively stouter ambulatory legs (Osawa, 2009; Fig. 1B, for E. palauensis).

Enosteoides melissa has been recorded from the intertidal region to the depth of $110 \mathrm{~m}$ in a wide area of the Indo-West Pacific ranging from Zanzibar to New Caledonia and south Japan (Haig, 1989; Osawa, 2007; 2009). However, it is usually regarded as an intertidal or shallow subtidal species and inhabits seagrass bed areas, judging from the habitat data of recently collected specimens (Osawa, 2009; 2013; present comparative material). The holotype of $E$. melissa was actually found under coral rocks in the low intertidal region (Miyake, 1942; Nakasone and Miyake, 1968). Additionally, field observations in the Ryukyu Islands of south Japan show that this species lives in burrows on seagrass beds; each burrow is usually occupied by one or two individuals of alpheid shrimp Alpheus rapax (rarely A. macellarius Chace, 1988), and/or one to three individuals of amphinomid polychaete Eurythoe cf. complanata (Osawa, 2013; pers. obs.). Enosteoides philippinensis is also an intertidal species and has been recorded from the outer area of mangrove forests (Dolorosa and Werding, 2014). Alternatively, many of the specimens of E. turkayi n. sp. examined were collected from depths more than $20 \mathrm{~m}$ and generally from the bottoms of sand and coral rubble or reef slopes, and it can be treated as a subtidal species that lives in deeper and coarser bottoms than $E$. melissa and E. philippinensis. Because of these habitat differences and the morphological similarity between E. melissa and E. turkayi n. sp., the specimens of $E$. melissa reported by Haig (1966 as Porcellana melissa; 1981 ; 1983; 1989) and Osawa (2007) from the western Indian Ocean, the Philippines, and New Caledonia (including the Loyalty Islands) need re-examination on if they actually represent that species. The material from the Philippines and New Caledonia was obtained at depths ranging from $20 \mathrm{~m}$ to $110 \mathrm{~m}$ (Haig, 1981; 1989; Osawa, 2007); the occurrence depths rather agree with those of E. turkayi n. sp. In particular, the specimen $(\mathrm{cl} 6.4 \mathrm{~mm})$ from New Caledonia reported by Osawa (2007) probably belongs to E. turkayi because it lacks a distinct row of plumose setae on the anterior margin of each chela; the character agrees with that of two large specimens examined ( $\mathrm{cl} 4.5 \mathrm{~mm}$ ) of the new species rather than the holotype and Japanese specimens examined of E. melissa.

Werding et al. (2016) reported the association among a goby, Alpheus Fabricius, 1798 shrimp, and E. lobatus sharing in a same burrow based on the direct field observations in Lembeh Strait, Indonesia. The habitat relationship is supposedly similar to that of $E$. melissa mentioned above. The images of $E$. lobatus given by Werding et al. (2016: fig. 1) show that the carapace is strongly uneven on the dorsal surface and the propodi of the ambulatory legs are dark red; these characters agree with those of the present new species rather than those of E. lobatus. The individuals illustrated by Werding et al. (2016) are probably referred to $E$. turkayi n. sp., although the association with a goby and Alpheus shrimp reported by Werding et al. (2016) is not recorded in the type material of the new species.

\section{ACKNOWLEDGEMENTS}

I thank Tomoki Kase of the National Museum of Nature and Science, Japan, for obtaining the crustacean material collected by tangle nets in Balicasag Island and making available the holotype of the new species for study. The PANGLAO 2004 Marine Biodiversity Project was collaboration between the Muséum national d'Histoire naturelle, Paris (Principal Investigator, Philippe Bouchet) and the University of San Carlos, Cebu (Principal Investigator, Danilo Largo). The Principal Investigators thank the Total Foundation for Biodiversity and the Sea, the French Ministry of Foreign Affairs, and the ASEAN Regional Center for Biodiversity Conservation (ARCBC) for funding. The Philippines Bureau of Fisheries and Aquatic Resources (BFAR) is acknowledged for issuing a research permit on the material collected by the "PANGLAO 2004". I am indebted to Peter K. L. Ng and Swee Hee Tan of the Lee Kong Chian Natural History Museum, the National University of Singapore, for making available for study the abundant porcellanid material collected in the PANGLAO 2004 Marine Biodiversity Project, and to Tin-Yam Chan of the National Taiwan 
Ocean University, for kindly taking photographs of E. palauensis and E. turkayi n. sp. used in this study. The manuscript benefited from helpful comments of Roy K. Kropp of the Pacific Northwest National Laboratory, Washington.

\section{ReferenCES}

Bouchet, P.; Ng, P.K.L.; Largo, D. and Tan, S.H. 2009. PANGLAO 2004 - Investigation of the marine species richness in the Philippines. In: S.H. Tan and M.E.Y. Low (eds), Crustacean supplement II. Raffles Bulletin of Zoology, Supplement 20: $1-19$.

Chace, F.A.Jr. 1988. The caridean shrimps (Crustacea: Decapoda) of the Albatross Philippine Expedition, 1907-1910, part 5: Family Alpheidae. Smithsonian Contributions to Zoology, 466: i-v + 1-99.

Dolorosa, R.G. and Werding, B. 2014. A new mangrove-inhabiting porcelain crab of the genus Enosteoides (Crustacea: Decapoda: Anomura) from Puerto Princesa Bay, Palawan, the Philippines. Bulletin of Marine Science, 90(3): 865-872.

Fabricius, J.C. 1798. Supplementum Entomologiae Systematicae. Hafniae, Proft et Storch, 380p.

Haig, J. 1966. Sur une collection de Crustaces Porcellanes (Anomura: Porcellanidae) de Madagascar et des Comores. Cahiers O.R.S.T.O.M., sèrie Ocèanographie, 3: 39-50.

Haig, J. 1978. Contribution toward a revision of the porcellanid genus Porcellana (Crustacea: Decapoda: Anomura). Proceedings of the Biological Society of Washington, 91(3): 706-714.

Haig, J. 1981. Porcellanid crabs from the Indo-West Pacific, Part II. Steenstrupia, 7(12): 269-291.

Haig, J. 1983. Porcellanidae (Decapoda, Anomura) from the Seychelles, western Indian Ocean. Crustaceana, 45(3): 279-289.

Haig, J. 1989. Porcellanidae (Decapoda, Anomura) collected during MUSORSTOM 1 and 2. In: J. Forest (ed), Rèsultats des Campagnes MUSORSTOM, Volume 5. Mémoires du Muséum national d'Histoire naturelle, Paris, section A, 144: 93-101.

Haswell, W.A. 1882. Description of some new species of Australian Decapoda. Proceedings of the Linnean Society of New South Wales, 6: 750-763.

Haworth, A.H. 1825. A new binary arrangement of the brachyurous Crustacea. The Philosophical Magazine and Journal, 65(322): 105-106, 183-184.

Johnson, D.S. 1970. The Galatheidea (Crustacea: Decapoda) of Singapore and adjacent waters. Bulletin of the National Museum Singapore, 35: 1-44.
Miyake, S. 1942. Studies on the decapod crustaceans of Micronesia. III. Porcellanidae. The Palau Tropical Biological Station Studies, 2(3): 329-379.

Nakasone, Y. and Miyake, S. 1968. A new species of Porcellana (Anomura: Porcellanidae) from the Palau Islands, with description of its related form. OHMU (Occasional Papers of Zoological Laboratory, Faculty of Agriculture, Kyushu University, Fukuoka, Japan), 1(7): 165-171.

Osawa, M. 2007. Porcellanidae (Crustacea: Decapoda: Anomura) from New Caledonia and the Loyalty Islands. Zootaxa, 1548: $1-49$.

Osawa, M. 2009. New records of three species of the genus Enosteoides Johnson, 1970 (Decapoda: Anomura: Porcellanidae) from Japan, with description of a new species. T. Komai and H. Komatsu (eds), New crustaceans of Japan. Bulletin of the National Museum of Nature and Science, Series A (Zoology), Supplement 3: 157-166.

Osawa, M. 2013. Enosteoides melissa (Miyake, 1942). p. 187. In: Japanese Association of Benthology (ed), Threatened animals of Japanese tidal flats: Red data book of seashore benthos. Hatano, Tokai University Press. [In Japanese]

Osawa, M. and Chan, T.-Y.2010. Part III. Porcellanidae (porcelain crabs). p. 67-181. In: T.-Y. Chan (ed), Crustacean fauna of Taiwan: Crab-like anomurans (Hippoidea, Lithodoidea and Porcellanidae). Keelung, National Taiwan Ocean University.

Osawa, M. and McLaughlin, P.A. 2010. Annotated checklist of anomuran decapod crustaceans of the world (exclusive of the Kiwaoidea and families Chirostylidae and Galatheidae of the Galatheoidea) Part II - Porcellanidae. In: M.E.Y. Low and S.H. Tan (eds), Checklists of anomuran decapod crustaceans of the world (exclusive of the Kiwaioidea and families Chirostylidae and Galatheidae of the Galathoidea) and marine lobsters of the world. Raffles Bulletin of Zoology, Supplement 23: 109-129.

Pallas, P.S. 1766. Miscellanea zoologica quibus novae imprimis atque obscurae Animalium species describuntur et observationibus iconibusque illustrantur. Hague, Hagae Comitum, 451p.

Stimpson, W. 1858. Prodromus descriptionis animalium evertebratorum, quae in Expeditione ad Oceanum Pacifi cum Septentrionalem, a Republica Federata missa, Cadwaladaro Ringgold et Johanne Rodgers Ducibus, observavit et descripsit. Pars VII. Crustacea Anomura. [Preprint (December 1858) from] Proceedings of the Academy of Natural Sciences of Philadelphia, 1858: 225-252.

Werding, B.; Christensen, B. and Hiller, B. 2016. Three way symbiosis between a goby, a shrimp, and a crab. Marine Biodiversity, doi:10.1007/s12526-016-0453-x.

Yang, S. and Sun, X. 2005. The Porcellanidae (Crustacea: Anomura) of Hainan Island, China with description of a new species. Natural Sciences and Museums, 1(1): 1-30. 